\title{
SYSTEMATIC NOTES ON AND DESCRIPTIONS OF NORTH AMERICAN WASPS OF THE SUBFAMILY BRACHY CISTIINAE
}

\author{
By J. R. Malloch,
}

Of the Bureau of Biological Survey, U. S. Department of Agriculture

In this paper are presented data obtained from a study of previously unidentified specimens in the collection of the Biological Survey and in the United States National Museum. This study was undertaken for the purpose of identifying a large number of species in the first-named collection which in their unidentified condition were of little value for comparative purposes to members of the Division of Food Habits Research in so tar as specific names were concerned. An intensive study of the anatomy of the groups dealt with was undertaken and drawings of the more important structures made by means of which it may be possible to identify, at least generically, even fragments of these insects such as are most frequently met with in the stomach contents of birds and other insectivorous animals. In this paper the illustrations deal with specific rather than group characters for the greater part, and where there are good figures in previously published papers of other authors these have not been duplicated.

One of the problems facing me at the start of this work was the status of the family Psammocharidae, as well as its position in the scheme of classification. The structure of the prothorax has for many years been considered to link this group with the Scoliidae, Mutillidae, and Sapygidae rather than with the Sphecoid complex; but I am not inclined to that opinion. In fact from a consideration of all the anatomical details of members of these groups I lean to the opinion that in the structure of the prothorax, and even more obviously in other characters both of biology and structure the Psammocharidae are more closely related to Sphecoidea than to Scoliidae. In a paper dealing with Psammocharidae I will enter more into details of these relationships.

Another problem that presented itself was the allocation of the genus Brachycistis. This genus has most recently been considered as belonging to the same group as Myrmosa and more specifically

No. 2604.-Proceedings U. S. National Museum, Vol. 68, Art. 3 $54291-26 \dagger-1$ 
as a member of the family Myrmosidae, though at one time the species now placed in the genus were considered as belonging to Mutillidæ and were linked with species of Cyphotes under that generic designation. It is my opinion that Brachycistis belongs to the Scoliidæ of which it should form a subfamily, or if one considers the major group as a super-family then it should be considered as a family in the complex. This family or subfamily status is largely a matter of opinion and until we have advanced farther in our knowledge of the Hymenoptera as a whole throughout the entire range of their occurrence a dogmatic opinion would be ill-advised.

Realizing that this work is merely a small contribution to the elucidation of the classification of the group upon which it is based and that with future accessions both of species and of workers it must be carried much farther I have deposited practically all my dissected specimens and types as well as all uniques and specimens not absolutely necessary for carrying on the work of the bureau of which I am a member in the collection of the United States National Museum where they will be accessible to any interested student.

\section{Family SCOLIIDAE}

In this family the pronotum is carried backward at its upper posterior angles to a point above the level of the tegulae where there is a rather sharp angle (fig. 1, 1a); the mesosternum is carried backward over or between the bases of the mid coxae in the form of a cleft plate; the apical ventral segment of the abdomen in the males is produced in the form of a single curved spine (figs. 2,3) or three such spines; the hind wing has the anal lobe present; the basal tergite of abdomen has a linear sulcus below spiracle extending from base to apex, beyond which the margin is flexed ventrad, closely adhering to surface of the sternite.

I present a key for the separation of the four subfamilies of Scoliidae that occur in North America. The females of Brachycistiinae are unknown, unless my surmise is correct that Mutilla peculiaris Cresson belongs here, an opinion that is expressed later on in this paper.

\section{Subfamily BRACHYCISTIINAE}

This subfamily is distinguished from the Myrmosidae by the venation of the fore wings (figs. 4, 5, 6), in which they more closely resemble Photopsinae; the forward opening antennal sockets; presence of a scalelike extension of the mesosternum between the bases of the mid coxae; the spinelike structure of the eighth abdominal sternite, in which character they are similar to Tiphiinae; the structure of the male hypopygium; and the lack of a platelike extension on hind coxae. 
The claws are simple; there is no stripe of fine short hairs on sides of second abdominal tergite in the males as in Mutillidae; the fore coxae possess a stridulatory area in most of the males; there is a distinct marginal vein as in Scoliinae, and Eliinae, though the connection of this vein with the one behind it at apex is different in Brachycistiinae from that shown in any of the related groups (figs. 7-11). In Brachycistiinae the cerci are absent, or at least not developed papilliform, in which character they are similar to Scoliinae and Tiphiinae, though these organs are present in Eliinae, and in Mutillidae and Myrmosidae (figs. 12, 13).

In Tiphiinae we have the same forwardly opening antennal sockets as in this subfamily, but the mesosternum and metasternum differ as indicated in the key presented below.

KEY TO SUBFAMILIES OF SCOLIIDAE

1. Antennal sockets directed obliquely laterad because of an abnormal development of the inner rim of each or an elevation of the intervening area; females winged.

-2 .

Antennal sockets directed forward, no abnormal development of the inner rim nor elevation of the intervening area

2. Metasternum broad and almost flat, consisting of two large, medially divided plates, the hind coxae widely separated.

Scoliinae.

Metasternum small, consisting of two tuberculiform plates, the hind coxae contiguous or subcontiguous Eliinae.

3. Tegulae entirely covering the antitegulae; metasternum large, on same plane as mesosternum or almost so, between the posterior plates of which it projects deeply as a triangular wedge; females always winged _. . _ Tiphiinae.

Tegulae normal, the antitegulae fully exposed; metasternum depressed, usually with two erect processes in front of hind coxae, or elevated ridge like on median line; females apterous _._. _. . . _ _. Brachycistiinae.

It appears to me that even using Ashmead's key to the families of Vespoidea Brachycistis males will run down to the vicinity of Tiphiidae and not to Myrmosidae, the mid coxae being overlaid basally by the posterior plates of the mesosternum and, though actually subcontiguous, quite as much separated as are those of some males of Elis, etc. The backward extensions of the mesosternum are lacking in the female which I assign here but the mid coxae are very widely separated.

I have but little hesitation in allocating as the female of Brachycistis the species upon which the genus Typhoctes was based, peculiaris Cresson. This sex which is known to me only from a single specimen, the type of mirabilis Cockerell, in the National Museum, and apparently the specimen used by Ashmead in describing Typhoctes, differs from the males of Brachycistis in having two apical spurs on the mid tibia, and a longitudinal stripe of short hairs on each side of the second abdominal tergite. Despite these discrepancies and the lack of wings I consider that this is the female of a species of 
Brachycistis, the other anatomical features being very much in favor of this view. I present a sketch of the thoracic anatomy from the side, showing the oblique pleural suture similar to that of males of Brachycistis (fig. 14), and the basal segment of the abdomen is. absolutely identical with that of the more robust males of that genus, while absolutely different from that of males of Cyphotes with which it has been more closely linked in the past (figs. 15, 16).

Males of Brachycistis are commonly attracted to lights where the species occur and when running about give forth a squeaking sound according to R. C. Shannon who collected specimens in Washington State. It may be of interest to state that I had noted the "stridulatory areas" on the fore coxae before I knew of the ability of theseinsects to produce sound, and that confirmation of my conjecturethat the insects stridulate was obtained from Mr. Shannon before he knew of my discovery. How these areas are used to produce sound or even if my surmise that they are so used is correct I do not know, but observation of living specimens will probably produceevidence if these areas are utilized in this manner.

Professor Cockerell in replying to a letter of mine in which I suggested that mirabilis might be the female of a species of Brachycistis: states that so far as he knows the former is diurnal and the Brachycistis males are nocturnal. However, he informs me that repeated searches with a lantern after dark in localities where the males. abounded failed to disclose any females of the genus, apparently bearing out the supposition we both entertain that the temales remain underground.

In the summer of 1924 the Biological Survey had E. R. Hall in the field at Pyramid Lake, Nev., and he picked up many specimens. of the genus Brachycistis which I have before me. A large number of these specimens were taken by sweeping alfalfa between the hours of 5 and $7 \mathrm{p.m}$. Others were taken at light. I give an extract from Mr. Hall's letter to me in reply to an inquiry of mine regarding the habits of these species.

The specimens of Hymenoptera labeled as having been swept from alfalfa were taken as early as $5 \mathrm{p}$. m. and as late as $7 \mathrm{p} . \mathrm{m}$. While those taken at the latter hour might be said to be crepuscular, none of the sweepings from alfalfa were made after dark and the ones taken as early as $5 \mathrm{p} . \mathrm{m}$. might indicate a diurnal habit. Large numbers were also taken at night under my light as indicated on the labels. I noticed that these insects produced a slight sound but. did not determine how this was accomplished.

It is of interest to note that all the specimens of atrata Blake in: this lot were swept from alfalfa, not one bearing a label to the effect that this black species occurred at light. Most of the orange colored specimens were taken at light, but a few have the same label as 
atrata and some others have no label to indicate how they were taken.

This record of the occurrence of a species in the daytime is of interest as the general opinion is that they are strictly nocturnal.

\section{Genus BRACHYCISTIS Fox}

The subfamily contains but one genus, which is divisible into at least three well defined segregates, one of which is made use of herein for the first time. These segregates, which I accept as subgenera, may be distinguished as in the following key.

KEY TO SUBGENERA

1. Mandibles with at most two teeth, sometimes with only a slight angle in addition to the apical tooth; fore wing with both recurrent veins and either two or three submarginal cells _........ Brachycistina, new subgenus, p. 25 .

Mandibles with two distinct teeth in addition to the apical one, or the second recurrent vein is lacking in forewing

2. Only one recurrent vein present in fore wing; fore coxae without a stridulatory

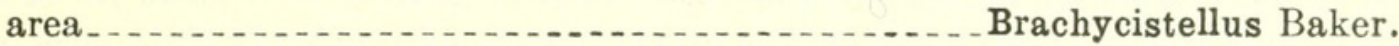

Two recurrent veins present in fore wing; fore coxae with distinct stridulatory area . . . . . Brachycistis Fox, p. 5.

\section{Subgenus Brachycistis Fox}

This subgenus contains most of the species and though these may be separated into segregates by more or less marked structural characters the groups are not so clearly differentiated that they can be considered as entitled to subgeneric status. I append a key to these groups and on subsequent pages keys to the species of each group known to me.

KEY TO SPECIES GROUPS

1. Second abdominal sternite with a short longitudinal carina at base.

aequalis group, p. 7 .

Second abdominal sternite without a longitudinal carina at base

2. Prepodeum with a sharp carina between the anterior horizontal and posterior declivous portions, or with irregular transverse rugae on upper part of hind surface _._.

Propodeum without a distinct transverse carina or obvious transverse rugae as above_...

3 Second submarginal cell of fore wing almost as long as first; but one round pitlike depression situated diagonally between metathoracic spiracle and suture; hind coxae sharp on postero-ventral (inner) surface, usually with a con-

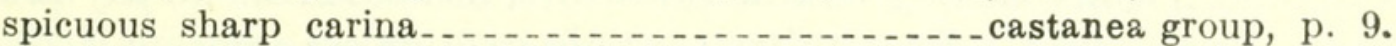

Second submarginal cell of fore wing very much shorter than first, averaging about half as long; two distinct pitlike depressions between the metathoracic spiracle and suture, one much above the other, postero-ventral margin of hind coxae rounded.................. carinata group, p. 10.

4. Fore wing with but two submarginal cells............. brevis group, p. 11. Fore wing with three submarginal cells . . . . . . 
5. Third submarginal cell of fore wing normally higher than long, the vein closing it outwardly interstitial with the cross vein from hind margin of stigma, or even proximad of it_............ 13.

Third submarginal cell of fore wing subquadrate or longer than high, the vein closing it outwardly much beyond the cross vein from hind side of stigma_._.

6. Head very conspicuously narrowed posteriorly, the sides converging from directly behind eyes when seen from above . . . . . . _ _ ampla group, p. 14.

Head normal, sides when seen from above generally parallel or subparallel

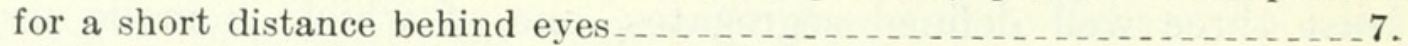

7. Space between antennal socket and eye not over one-half as wide as one socket; posterior ocelli separated from eye by a distance not greater than the transverse diameter of either ocellus; anterior extremities of gular carina visible from side except in nigripes ........ inaequalis group, p. 15.

Space between antennal socket and eye distinctly more than half as wide as socket. -8 .

8. Posterior ocelli separated from eye by a space at least 1.5 as wide as one ocellus micrommata group, p. 17.

Posterior ocelli separated from eye by a space less than 1.5 as wide as one ocellus

9. Gular carina not elevated and deflected outwardly at or near its anterior extremities, never visible when head is viewed directly from the sides; vein emanating from apical costal margin of stigma extending along costa as far as or farther than length of the cross vein emanating from hind side of stigma nitida group, p. 20.

Gular carina with its anterior extremities visible when head is seen from the side, or if these elevations are not visible, or indistinctly so, the vein emanating from apical costal margin of stigma bends down at, or very close to, its base and does not run along costa as far as stated in last section.

atrata group, p. 22 .

Bradley separates two species, eriopis Bradley and arenivaga Bradley, from all the others on the structure of the basal segment of the abdomen. In these two this segment has no basal neck and there is no dorsal, and scarcely any lateral, constriction between it and the second segment. I have seen no specimens that possess this character. Bradley figures the hypopygium of arenivaga and, though the details are not very clear, it evidently is very similar to that of atrata Blake, as is also the venation of the fore wing, which he figures, too.

Bradley included 30 species of Brachycistis in the restricted sense in his paper. Of these I have seen 22 and some of the others are included in my keys on the strength of characters given by Bradley. A few are omitted as it is impossible for me to include them owing to the descriptions lacking characters which are essential to my placing them in my paper. The omitted species include perpunctata Cockerell petiolata Fox, ioachinensis Bradley, nuda Fox, subquadrata Fox, and the two already referred to. I believe that the absence of the carina on the upper margin of occiput will readily distinguish the firstnamed species from any other yet described, and nuda Fox appears to me to be a synonym of atrata, which Bradley evidently suspected from his remark that it was "doubtfully distinct from atrata." 
AEQUALIS GROUP

1. idiotes Cockerell.

2. noctivaga Bradley.

3. aequalis Fox.

4. normalis Malloch.

CASTANEA GROUP

5. crassa Bradley.

6. stygia Bradley.

7. castanea Cresson.

8. thermarum Bradley.

CARINATA GROUP

9. rugosa Malloch.

10. carinata Fox.

11. subcarinata Malloch.

BREVIS GROUP

12. texana Malloch.

13. brevis Fox.

14. eremi Bradley.

GAUDII GROUP

15. gaudii Cockerell.

16. parva Malloch.

AMPLA GROUP

17. ampla (Blake).

18. protractor Bradley.
INAEQUALIS GROUP

19. nigrifrons Malloch.

20. inaequalis Fox.

21. curvata Malloch.

22. utahensis Malloch.

23. alcanor Blake.

24. dentata Bradley.

MICROMMATA GROUP

25. micrommata Bradley.

26. intermedia Malloch.

27. melanocephala Malloch.

28. verticalis Malloch.

29. dakotensis Malloch.

NITIDA GROUP

30. nevadensis Fox.

31. nitida (Cresson).

32. washingtona Malloch.

33. glabrella Cresson.

ATRATA GROUP

34. atrata (Blake).

35. imitans Malloch.

36. lacustris Malloch.

37. indiscreta Fox.

38. semiatra Malloch.

39. triangularis Cresson.

\section{AEQUALIS group}

Characters.- Second abdominal sternite with a conspicuous longitudinal carina on basal portion; distance from apex of stigma to apex of marginal cell not less than two-thirds as great as length of stigma; propodeum with a distinct transverse carina between horizontal and declivous sections; hind coxae without a longitudinal carina on their posteroventral, or inner opposed surfaces. Male hypopygium as in figure.

KEY TO SPECIES

1. Basal segment of abdomen when seen from above at least 2.5 as long as its apical width, when seen from the side about three times as long as its greatest height; sternal carina short and not very high _. _idiotes Cockerell.

Basal segment of abdomen when seen from above distinctly less than twice as long as its apical width, when seen from the side not over twice as long as its greatest height.

2. Carina of gular orifice produced into a sharp elevation at its anterior extremity which is plainly visible from the side when the head is held in a vertical

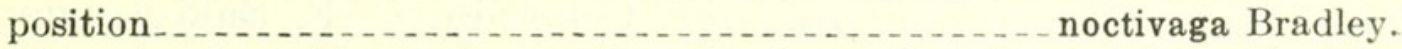

Carina of gular orifice not exceptionally elevated at its anterior extremity which is not visible when the head is held in a vertical position ........ 3 .

3. Basal abdominal segment about twice as long as its apical width when seen from above; apical edge of clypeus very little elevated ....... aequalis Fox.

Basal abdominal segment distinctly less than twice as long as its apical width when seen from above; apical edge of clypeus quite noticeably elevated normalis, new species. 
A large slender species with the same form of hypopygium as noctivaga, in fact there are no outstanding distinctions between these organs in any of the four species of the group, all of which I have examined. The characters listed in the key appear to warrant the specific separation of the four forms. The inner one of the paired processes of hypopygium (Sagitta of Bradley) is shorter than in normalis (fig. 43), otherwise the hypopygium is similar.

Length, $15-18 \mathrm{~mm}$.

Originally described from Las Cruces, N. Mex. I have seen it from Keeler, Calif., November 14, 1914 (A. Wetmore).

\section{BRACHYCISTIS (BRACHYCISTIS) NOCTIVAGA Bradley}

A much stouter species than the last, the first abdominal segment being conspicuously stouter. The quite conspicuous elevation of the gular carina at its anterior extremity (fig. 30) readily separates this species from the next two, but in this character it is similar to idiotes.

Length, $12-14 \mathrm{~mm}$.

Originally described from Las Vegas, Nev. I have before me specimens from Arlington, Higley, and Mount Superstition, Ariz., and one from Utah without more definite locality.

\section{BRACHYCISTIS (BRACHYCISTIS) AEQUALIS Fox}

This species has the first abdominal segment more elongate than in noctivaga or normalis, and in the specimen before me there is an irregular transverse carina on first tergite just behind the spiracles. The occiputal carina in this species is as shown in Figure 29. The marginal cell of fore wing is about as long on costal margin as the stigma.

Length, $12 \mathrm{~mm}$.

Recorded from Colorado, Nevada, and Arizona. The only specimen I have seen is from Arizona.

\section{BRACHYCISTIS NORMALIS, new species}

Male. - Similar to noctivaga in all respects except the structure of the gular carina. Hypopygium as in figure 43.

Length, $12-14 \mathrm{~mm}$.

Holotype.-Cedar Pass, S. Dak. (W. H. Over). Paratypes, two, San Simon, Ariz. (Hubbard), one, Colorado (C. F. Baker), one, Los Angeles county, Calif.

Type.-Cat. No. 27909, U. S. N. M. 


\section{CASTANEA group}

Characters.-Hind coxae sharply carinate on posteroventral margins, less conspicuously so in thermarum Bradley; propodeum with a distinct transverse carina as in idiotes group; second submarginal cell of fore wing about as long as first; second sternite of abdomen without a longitudinal carina; first abdominal segment not twice as long as its apical width when seen from above; mid and hind tibiae with distinct dorsal bristles or spines; only one pit below metathoracic spiracle instead of the usual two.

\section{KEY TO THE SPECIES}

1. Second abdominal sternite with a transverse elevation near base; first: tergite with a similar but less distinct ridge or elevation near middle....... crassa Bradley.

Second sternite and first tergite normal, without transverse elevations.... 2 .

2. Deep black species. stygia Bradley.

Castaneous or brownish orange colored species.

3. Hind coxal carinae very sharp and conspicuous........ castanea Cresson. Hind coxal carinae more rounded, inconspicuous........ thermarum Bradley .

\section{BRACHYCISTIS (BRACHYCISTIS) CRASSA Bradley}

This is the only known species of the genus in which the second abdominal tergite is transversely carinate near base. The hypopygium is quite distinct from that of any other species of the genus belonging to any group. The figures which I present of the organ (figs. 44, 45) are considerably different from those given by Bradley for this species, but the disparity may be due to a difference of viewpoint, or to individual variation within the same species. The two small figures given above the uncus show lateral and end views of that organ.

All the species of the group except stygia are brownish-orange or castaneous in color, the head being but little if any darker than the thorax. Bradley gives good figures of the wings of all four species, showing their striking similarity.

Length, 13-15 mm.

Originally described from southern California. I have before me specimens from Graham Mountains, Tucson, Arlington, Fort Grant, and Gila Valley, Ariz.

\section{BRACHYCISTIS (BRACHYCISTIS) STYGIA Bradley}

A robust, coarsely punctate black species which is conspicuous from the more slender shining black species like gaudii Cockerell and atrata Blake by its larger size, $13-15 \mathrm{~mm}$. in length, and the characters listed in key to groups. I present figures of the hypopygium (figs. 42, 46).

Originally described from Arizona. I have before me a series of specimens taken at Higley and Mount Superstition, Ariz.

$54291-26 \dagger-2$ 


\section{BRACHYCISTIS (BRACHYCISTIS) CASTANEA Cresson}

Apparently a fairly common species. Recorded from Colorado, New Mexico, and Lower California. I have seen specimens from Arizona, Texas, and California. The hypopygium differs slightly from that of stygia as shown by the sectional drawings $46, a, b$, and $c$.

\section{BRACHYCISTIS (BRACHYCISTIS) THERMARUM Bradley}

This species has the hind coxae less distinctly carinate than the others in the group, and the hypopygium is rather different in some particulars as shown in figure 46 and 47 .

Length, $115-13 \mathrm{~mm}$.

Originally described from Hot Springs, Ariz. I have seen specimens from Higley, Mount Superstition.

\section{CARINATA group}

Characters.-Propodeum with one sharp or well-defined carina demarcating the horizontal anterior and declivous posterior parts, or there are several more or less irregular transverse carinae on the upper margin of the declivous part; hind coxae rounded on posteroventral margins; second abdominal sternite more carinate; first segment longer than its apical width.

The species in this group, despite the presence of a more or less obvious transverse carina on the propodeum, appear to be more closely related to the atrata group than to the castanea group, judging from the structure of the hypopygium (fig. 43).

Throughout the group the head is black, the hind coxae are not carinate, and the second submarginal cell of the fore wing is much shorter than the first, readily distinguishing them from the pale colored species of the castanea group.

There appear to be three species in the group represented in my material. I find very little structural variation in the large series of carinata which I have examined from a single locality and were it not for this fact I might be inclined to consider the specimens here described as new species to be merely aberrant examples of carinata. The hypopygia present no tangible differences, but this is not unusual in this genus where other and striking structural distinctions evidently outweigh the evidence of the hypopygia in separating species in several of the groups.

KEY TO SPECIES

1. Dorsum of propodeum irregularly transversely rugose, the division between the dorsal and hind surfaces with two irregular rugae; basal segment of abdomen about three-fourths as wide as at apex as it is long

Dorsum of propodeum without transverse rugae, finely shagreened, and with a median sulcus. 
2. Division between dorsal and hind surfaces of propodeum marked by a single carina which is usually quite sharp; basal segment of abdomen nearly twice

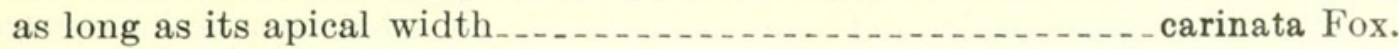

Division between dorsal and hind surfaces of propodeum marked by two or more irregular series of transverse rugae; basal abdominal segment with its apical width fully two-thirds as great as its length

subcarinata, new species.

BRACHYCISTIS (BRACHYCISTIS) RUGOSA, new species

Male.-Similar to carinata, but a little darker in color. Differs structurally in the characters listed in the key and as follows: Antennal sockets but little produced below, not sharply so; central beveled emargination of clypeus broader centrally, narrower laterally, the emargination deeper; anterior elevations of gular carina higher, visible when head is viewed directly from the side.

Length, $12 \mathrm{~mm}$.

Holotype.-Golconda, Nev. September, 1915 (J. R. Bunch).

Type.-Cat. No. 27910, U.S.N.M.

\section{BRACHYCISTIS (BRACHYCISTIS) CARINATA Fox}

This species is more slender than rugosa. Hypopygium as in figure 48 .

Length, $12-14 \mathrm{~mm}$.

Originally described from La Jolla, Calif., from which locality I have seen a specimen in the United States National Museum. A large series from San Diego in same collection.

\section{BRACHYCISTIS (BRACHYCISTIS) SUBCARINATA, new species}

Male.-Very similar to carinata, differing as stated in key and as follows: Head almost as in rugosa; propodeum more nearly vertical behind; color darker.

Length, $12 \mathrm{~mm}$.

Holotype.-Higley, Ariz., June 18, 1917, at light (E. G. Holt).

Paratype.-Arlington, Ariz., June 16, 1919, at light (A. Wetmore).

Type.-Cat. No. 27911, U.S.N.M.

\section{BREVIS group}

Characters.-Only two submarginal cells in fore wing; propodeum without a transverse carina; second abdominal sternite not carinate; hind coxae slightly carinate on posteroventral edge except in texana.

KEY TO SPECIES

1. Carina of gular orifice elevated into a prominent angle less than midway from hind to front margin (fig. 32); hind coxae rounded on posteroventral edges; clypeus with a rounded vertical elevation apicad of which the surface slopes slightly, the apical margin emarginate and flattened.

-texana, new species.

Carina of gular orifice not elevated about middle; clypeus with a more or less beaklike central eminence; hind coxae sharp, almost carinate on posteroventral edges. 
2. Carina of gular orifice quite noticeably elevated and very thin at anterior extremities eremi Bradley.

Carina of gular orifice not more thinned nor elevated at anterior extremities than elsewhere brevis Fox.

BRACHYCISTIS (BRACHYCISTIS) TEXANA, new species

Male.-Pale brownish-orange, tips of mandibles and stigma fuscous.

Posterior ocelli about 1.5 their own width from eye, separated from each other by about twice their own width, and from anterior ocellus by a space equal to the width of either; frons very sparsely punctured, and with no ridges in front, barely visible above antennae when head is viewed directly from side; clypeus with a quite prominent longitudinal broadly rounded eminence in center which has its apex about midway from upper to lower margin, the beveled portion of apical margin broader and less abrupt than usual, tooth on each side of central emargination distinct; space between edge and antennal socket a little narrower than socket, mandible with a ridge from base of inner tooth which becomes rounded from middle to base; gular carina as in Figure 32, the sharp angle nearer hind than front margin; antennae crenulate; pronotum almost vertical, not rugose; mesopleura with rather large punctures, most numerous anteriorly; propodeum broadly rounded above, rather abruptly declivous posteriorly, without ridges or depression above, the lateral upper margins with some setiforous punctures. First abdominal segment very little larger than its apical width, the constriction between it and second well defined; hypopygium as in Figure 49. Venation of forewing as in eremi Bradley. Mid and hind tibiae each with three or more quite strong dorsal bristles.

Length, $7 \mathrm{~mm}$.

Holotype.-Cotulla, Tex., May 12, 1906, at light (Crawford and Pratt), Cat. No. 27912, U.S.N.M.

\section{BRACHYCISTIS (BRACHYCISTIS) EREMI Bradley}

Very similar to brevis distinguished by the characters cited in key and in notes under last species. The minute hypopygial characters shown in figures 37-39 may not be sustained in a large series of specimens, but are the only distinctions I find in comparing single examples of the two species.

Length, 7-9 $\mathrm{mm}$.

Originally described from Calexico, Calif. I have before me seven specimens from Higley, Mount Superstition, and Arlington, Ariz., June 15 and 16, and July 7 and 20 (A. Wetmore, E. G. Holt) and two specimens from Hot Springs, Ariz., June 22 and 26 (Barber and Schwarz). The last two specimens are from the National Museum collection, the others are from the collection of the Biological Survey. 


\section{BRACHYCISTIS (BRACHYCISTIS) BREVIS FOX}

This species is sometimes distinguishable from eremi by the venational character cited by Bradley, consisting of the comparative length of the first and second submarginal cells, but not invariably so, as the second is sometimes nearly as long as first in both species. I have found however that the differences in the carinae surrounding the gular orifice present a reliable means for the separation of the species as cited in the key. The propodeal distinction cited by Bradley is not dependable, as both species show considerable variation in the degree of puncturation. The genitalia are strikingly similar, both having the same general habitus. There are minute distinctions however as shown in figures $37-39$.

Length, 7-9 mm.

Originally described from California and recorded by Bradley from Calexico, Calif. I have before me 10 specimens from Higley and Arlington, Ariz., June 16 and July 7, mostly taken at light (A. Wetmore, and G. Holt).

\section{GAUDII group}

In Bradley's key there are three species linked with gaudii on the same character used in my key to groups. Of these three I have relegated elegantuila Cockerell to another group because of the presence of only two mandibular teeth. Bradley does not make any mention of indiscreta Fox in his text, but on the basis of an examination of a specimen in the National Museum labeled "type" I consider this species does not belong to this group, thus we have left only two species, petiolata Fox, and gaudii Cockerell, the former of which I have not seen.

In the two species before me the gular carina is slightly outwardly deflected at its anterior extremity, the deflected part rounded in outline and widely separated from condyle of mandible. Both species have a small round tubercle in middle of clypeus and beyond that the margin is beveled off anteriorly. The propodeum is slightly roughened or sharpened and the first abdominal segment is about twice as long as its apical width. Hypopygium of gaudii as in atrata Blake.

\section{DIAGNOSIS OF SPECIES}

Black species; posterior ocelli separated from eye by a space at least 1.5 as great as their own transverse diameter; space between eye and antennal socket about as wide as socket_._._._._.

Brownish orange species, the head castaneous above; posterior ocelli separated from eye by a space hardly greater than their own transverse diameter; space between eye and antennal socket about half as wide as socket.

parva, new species.

BRACHYCISTIS (BRACHYCISTIS) GAUDII Cockerell

Resembles a small specimen of atrata Blake, but quite different in venation of fore wing (figs. 6,17 ), and in the wider space between eyes and posterior ocelli. 
Originally described from La Jolla, Calif., and not seen by Bradley, who states that Professor Cockerell informed him the type is in the National Museum. I have been unable to find the type, but have before me a large series of males taken at San Diego, Calif.

\section{BRACHYCISTIS (BRACHYCISTIS) PARVA, new species}

Male.-Differs from gaudii Cockerell as stated in diagnosis. B. petiolata Blake is larger, $8 \mathrm{~mm}$. in length, and has the propodeum with the sides of the dorsal surface and the postero-lateral angles rugose; the general color is rather uniformly dark castaneous. The new species has the propodeum microscopically shagreened above and along upper margins of sides.

Length, $5 \mathrm{~mm}$.

Holotype.-California (C. F. Baker).

Type.-Cat. No. 27913, U.S.N.M.

I have also before me a specimen which is $7 \mathrm{~mm}$. in length, agrees in color with parva, except that the head is black above and the body darker, and has the posterior ocelli at a little less than their transverse diameter from eyes. The propodeum is more coarsely shagreened than in parva, but not rugose as Bradley says is the case in petiolata. It is possible that this specimen represents another species, but more material is desirable before describing it.

Locality.-Arlington, Ariz., June 16, 1919 (A. Wetmore).

\section{AMPLA group}

I assign to this group besides ampla Blake, protracta Bradley. I have not seen the latter, but Bradley says they are very closely related. He makes no mention of the peculiar posteriorly narrowed head. In both species the gular carina is elevated at anterior margin and deflected outwardly at that point. Bradley's characters for distinguishing them are as follows:

Head 0.4 wider than minimum distance between the tegulae; petiole, viewed from the side, evenly but slightly enlarged posteriorly, four times as long as its dorso-ventral thickness; mandible without a carina on the upper surface at base; $R_{\text {}}$ not meeting $r-m$ at an angle, the cell $R_{5}$ therefore triangular; color dark castaneous. Length $20 \mathrm{~mm}$.............. protracta Bradley. Head one-tenth wider than minimum distance between the tegulae; petiole suddenly widened toward its apex, three and one-half times as long (measured along the side) as its greatest dorso-ventral thickness; each mandible with a strong carina along its upper surface, arched into a tooth near its base; $R$, meeting $\mathrm{r}-\mathrm{m}$ at an angle, the cell $\mathrm{R}_{s}$ therefore four sided; color brownishyellow. Length, $14 \mathrm{~mm}$

\section{BRACHYCISTIS (BRACHYCISTIS) AMPLA (Blake)}

I have before me a number of examples of this species, some of which are about $20 \mathrm{~mm}$. in length while others are about $14 \mathrm{~mm}$. The petiole of the abdomen is in some of these specimens quite four times as long as its greatest dorso-ventral thickness, but the 
third submarginal cell shows width narrowing above. I assume that protracta is a distinct species, but the characters quoted above are not to be accepted as criteria in their entirety for their differentiation.

I have seen ampla from Colorado, from which State it was originally described, and from Washington State.

\section{INAEQUALIS group}

Characters.-Distinguished from others by the narrow space between the eyes and the antennal sockets, which is not more than, and often considerably less than, equal to half the width of the socket. The face is much narrowed below, the space between the eyes at narrowest point being distinctly less than the distance across posterior ocelli. The space between the eyes and posterior ocelli is never appreciably greater than the transverse diameter of one ocellus, and is often distinctly less.

\section{KEY TO SPECIES}

1. Hind tibiae without pronounced dorsal bristles, sometimes with a weak one near middle; mandibles without a pronounced angle between inner tooth and base . . . . .

Hind tibiae with some pronounced bristles on dorsal surface extending from before middle to apex, or if these are weak or sparse the mandibles are distinctly angulate between inner tooth and base................. 4 .

2. Anterior extremities of gular carina not visible below condyle when head is seen from side; head black above; vein emanating from apical costal angle

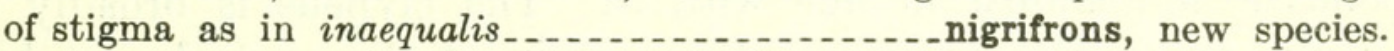

Anterior extremities of gular carina distinctly visible when head is seen from the side . _

3. Head dark castaneous above; vein emanting from apical costal angle of stigma bent down just after leaving latter (fig. 22) .......... curvata, new species.

Head little if any darker than thorax and abdomen; vein emanating from apical costal angle of stigma running along costa for a short distance before bending down (fig. 20)

4. Mandible without an evident angle between base and inner tooth . . . . . . .

(See nitida group).

Mandible with a pronounced angle between base and inner tooth _........ 5 .

5. A line drawn across the highest points of deflexed anterior parts of gular carina would pass through the mandibular condyle; hind tibiae each with one or two weak bristles about middle _...

A line drawn across the highest points of deflexed anterior parts of gular carina would pass behind the mandibular condyles, hind tibia with quite strong dorsal bristles; head brownish orange.............. alcanor Blake.

6. Head black above; clypeus with a small but rather prominent tubercle in

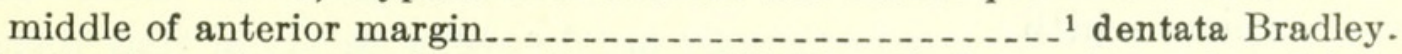

Head pale castaneous above; clypeus with its apical margin produced into a short transverse edge which is slightly rounded in outline, the elevated portion as wide as space between antennal sockets__utahensis, new species.

1 The space between antennal socket and eye in this species appears to be variable in width or else there are two closely allied species present in my material. In any case I have included dentata in two of my keys leaving the specific status of these forms for future investigation. 
BRACHYCISTIS (BRACHYCISTIS) NIGRIFRONS, new species

Male.-Shining brownish orange, frons and upper part of face glossy black.

Space between outer ocellus and eye less than that of ocellus; space between antennal socket and eye about half as wide as socket; mandibles without an angle near base; clypeus but little emarginate, the raised part not sharp and but little more elevated in center. Propodeum with dorsal part almost as long as wide, evenly and broadly rounded, without a pronounced median sulcus, the edges rounded off, posterior face and upper margins of sides with setiferous punctures. First segment of abdomen twice as long as high, and about 1.5 as long as its apical width. Two or three of the dorsal hairs on hind tibia strong but not conspicuously so. Venation as in inaequa lis.

Length, 9-10 mm.

Type and one paratype-Graham Mountains, Ariz., Ash Creek, 3,200 feet, June 15, 1914 (E. G. Holt).

Type and paratype.-Cat. No. 27921, U.S.N.M.

\section{BRACHYCISTIS (BRACHYCISTIS) INAEQUALIS Fox}

This species has the hypopygium similar to that of atrata Blake. The marginal cell of fore wing is as in figure 20. When the head is viewed from the side the apex of the anterior elevation of the gular carina is quite clearly visible below the level of the mandibular condyle and almost in line with it. The clypeus is broadly and evenly emarginate in center, the margin of the central part being very little elevated and without a central tubercle; the space between eye and antennal socket is very narrow, that between eye and posterior ocelli a little narrower than transverse diameter of the ocellus. Propodeum broad, evenly rounded, and with rather coarse setiferous punctures posteriorly, laterally. Basal segment of abdomen about 1.25 as long as its apical width.

Length, 10-12 $\mathrm{mm}$.

Originally described from Los Angeles, Calif., from which locality I have many specimens before me. I have also some from Texas.

BRACHYCISTIS (BRACHYCISTIS) CURVATA, new species

Male.-Differs from inaequalis as stated in key and as follows: More slender; propodeum with a broad shallow sulcus on anterior part of dorsum in center; first abdominal segment about 1.5 as long as its apical width.

Length, $10 \mathrm{~mm}$.

Holotype.-Arizona (C. F. Baker). Paratype, Fort Mohave, Ariz. (Junius Henderson).

Type and paratype.-Cat. No. 27919, U.S.N.M. 
BRACHYCISTIS (BRACHYCISTIS) DENTATA Bradley

Male.-Head dark castaneous, almost black above; thorax and abdomen brownish orange; stigma dark brown.

Space between eye and posterior ocelli about equal to transverse diameter of either ocellus and to space between posterior ocelli and anterior ocellus; a slight transverse ridge above each antennal insertion; space between edge and antennal socket almost linear; clypeus with a rather beaklike tubercle on its lower margin in middle, beyond which the edge is abruptly beveled, the submedian angles not noticeably toothlike; mandibles stout, the upper edge sharp and rather conspicuously angled near base; gular carina much as in inaequalis. Propodeum finely shagreened dorsally and with or without central sulcus, the sides above and posterior surface with setiferous punctures. First segment of abdomen fully as long as its apical width. Hind tibial bristles not conspicuous, and sparse.

Length, $8 \mathrm{~mm}$.

Locality.-Flagstaff, Santa Rita Mountains, and Fort Grant, Ariz., Mesilla and Lordsbury, N. Mex.; Colorado, and San Bernardino, Calif.

Originally described from New Mexico.

BRACHYCISTIS (BRACHYCISTIS) UTAHENSIS, new species

Male.--Very similar to the preceding species, differing as stated in the key. The sulcus on propodeum is more distinct than in the last species the basal abdominal segment shorter, and the size greater.

Length, $10 \mathrm{~mm}$.

Holotype.-Utah (C. F. Baker).

Type.-Cat. No. 27920, U.S.N.M.

\section{BRACHYCISTIS (BRACHYCISTIS) ALCANOR Blake}

If my interpretation of this species is correct it varies considerably in size, intensity of puncturation, size of ocelli, and some other characters. It is possible, however, that a careful scrutiny of more material from the various localities listed below will prove that there is more than one species in the lot now before me, which fact I can not demonstrate satisfactorily at this time.

Length, $7-15 \mathrm{~mm}$.

Originally described from Arizona. Specimens in the collections here are from Arizona, and Los Angeles County, Calif.

\section{MICROMMATA group}

Characters.-Distinguished by the small size of the ocelli, the posterior pair being separated from the eyes by a distance almost or quite twice as great as the transverse diameter of one ocellus.

I have not seen micrommata Bradley, but use the characters given by Bradley for distinguishing it from the new species in the following diagnosis. 
1. Black species; clypeus with a raised marginal point; carina extending from inner tooth to base of mandible strongly, but not angularly, elevated near base micrommata Bradley.

Brownish-orange species -2 .

2. Head concolorous with thorax, brownish-orange; mandible with a carina from inner tooth to base which is not appreciably elevated near base $\ldots \ldots \ldots . . . .3$.

Head black, contrasting with the brownish-orange thorax; mandible with a carina from inner tooth to base which is prominently elevated near base -4 .

3. Clypeus with a short thin transverse elevation or lip in center of apical margin, the edge very narrowly and steeply beveled beyond it; anterior elevation of gular carina in line with mandibular condyle, close to it and deflexed.... .

Clypeus with a vertical rounded elevation in middle, the apical edge narrowly beveled; anterior elevation of gular carina behind mandibular condyle, remote from it, and deflexed................ verticalis, new species.

4. Propodeum smooth above; extreme height of first abdominal segment as seen from the side less than half as great as length of segment along lateral

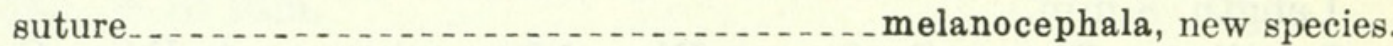

Propodeum finely striate on each side on dorsum; extreme height of first abdominal segment over half as great as length of segment along lateral

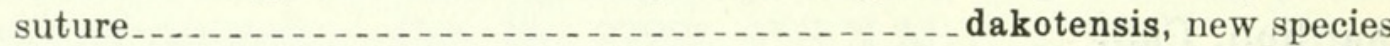

\section{BRACHYCISTIS (BRACHYCISTIS) MICROMMATA Bradley}

Bradley's synoptic description of the color, etc., of this species is as follows: Black, the tarsi and antennæ brown, the latter dark except at base; sparsely clothed with somewhat yellowish pile; wings hyaline, slightly infuscated beyond stigma, which is piceous; veins brownish-yellow to piceous.

Length, $8 \mathrm{~mm}$., slender.

The head of this species must differ in many details from that of melanocephala, as indicated by the characters here taken from the original description. Measurements of ocelli, etc.: Posterior ocellus, diameter, $0.17 \mathrm{~mm}$; distance of posterior ocellus from eye, 0.3 ; distance between posterior ocelli, $0.38 \mathrm{~mm}$; inferior margin of antennal socket thickened, with a downward projecting triangular tubercle. The clypeus and mandibles are apparently similar to those of melanocephala but no mention is made of the structure of the gular carina. The venation of the fore wing as figured by Bradley is the same as that of melanocephala.

Originally described from Berkeley, Calif. Type in Cornell University.

BRACHYCISTIS (BRACHYCISTIS) INTERMEDIA, new species

Male.-Brownish-orange. Tips of mandibles castaneous. Stigma fuscous.

Head above similar to that of texana; space between posterior ocelli and eye about twice as wide as transverse diameter of either ocellus; space between eye and antennal socket equal to socket; 
gular carina with a prominent elevation near anterior extremity on each side, which is deflexed to sides, plainly visible below condyle when head is seen from side, and almost in line with condyle. Propodeum rather stout, with a sulcus in middle anteriorly, the posterior and upper lateral parts with numerous setiferous punctures. First abdominal segment at most 1.5 as long as its apical width. Marginal cell of fore wing as in figure 24 .

Length, 7-9 $\mathrm{mm}$.

Holotype and 12 paratypes.-San Diego, Calif. (Ricksecker).

Type and paratypes.-Cat. No. 27922, U.S.N.M.

BRACHYCISTIS (BRACHYCISTIS) VERTICALIS, new species

Male.-Colored as intermedia.

Space between posterior ocelli and eye not much over 1.5 as great as width of either ocellus, and twice as wide as space between anterior and posterior ocelli. Space between eye and antennal socket as wide as socket; clypeus convex, centrally elevated in the form of a rounded vertical carina, the edge narrowly beveled on emarginate central portion, the submedian angles not prominent; mandibles without an angle between inner tooth and base; gular carina quite conspicuously and sharply elevated on each side at a little distance behind the transverse line of the mandubilar condyles, the gular orifice at its anterior margin hardly wider than the space between it and either eye. Pronotum not depressed and abruptly declivous in front, rather evenly rounded; mesopleura glossy, with large punctures; propodeum short and stout, with a shallow dorsal sulcus, the sides above and posterior surface rather coarsely punctured. First abdominal segment not longer than its apical width. Hind tibia with quite conspicuous dorsal bristles. Vein bounding costal margin of marginal cell bent down close to stigma. Anterior cross-vein of hind wing $\left(R_{4}\right)$ erect, not shorter than $R_{8}$

Length, $10 \mathrm{~mm}$.

Holotype.-Fort Grant, Ariz., July 19 (Hubbard).

Type.-Cat. No. 27923, U.S.N.M.

BRACHYCISTIS (BRACHYCISTIS) MELANOCEPHALA, new species

Male.-Head black, mandibles, antennae, and palpi, brownish orange, clypeus darker. Thorax, abdomen, and legs brownish orange, abdomen dark brown apically. Wings clear, veins yellow, stigma brown.

Frons when seen from side projecting above the upper level of eye distinctly more than height of ocellus exclusive of latter; space between antennal socket and eye a little greater than width of socket; the latter without a noticeable thickening below, not tuberculate; clypeus as in figure 33 ; mandible with a sharp ridge extending from inner tooth to base, which is rather angularly produced near base; gular carina elevated in line with condyle at base of mandible, 
visible above latter when head is seen from side, the elevated portion not horizontal but beveled off internally so that when it is seen from below it presents a flattened surface with a ridge along its outer side which is directed obliquely laterad; posterior ocellus half as wide as space between it and anterior ocellus; distance between posterior ocelli and that between either and eye subequal. Propodeum smooth and evenly rounded above, posteriorly and on sides above with some setigerous punctures. Basal abdominal segment about one-fifth as long as its apical width, distinctly constricted from second. Second and third submarginal cells subequat, both combined about as long as greatest length of first.

Length, $8 \mathrm{~mm}$.

Holotype.-Currant Creek, 8,000 feet, Uinta National Forest, Utah, August 13, 1917 (J. Silver).

Type.-Cat. No. 27924, U.S.N.M.

There is a specimen from Fort Grant, Arizona, in the National Museum which may represent another species. It has the posterior ocelli a little nearer to eyes and might be considered as belonging to the nitida group.

\section{BRACHYCISTIS (BRACHYCISTIS) DAKOTENSIS, new species}

Male.-Similar to preceding species, but stouter and darker colored besides differing as stated in the key.

Length, $9 \mathrm{~mm}$.

Holotype.-Edgemont, S. Dak., August 6, 1915 (E. G. Holt).

Type-Cat. No. 27925, U.S.N.M.

\section{NITIDA group}

In this group the gular carina is not elevated and flexed outward at or near its anterior extremities, its anterior extremities never being visible below the mandibular condyle when the head is viewed directly from the side; and the vein emanating from apical costal angle of stigma extends along costa at least as far as length of crossvein emanating from stigma.

\section{KEY TO SPECIES}

1. Gular orifice at its anterior margin hardly wider than space between anterior extremities of gular carina and eye, first abdominal segment over twice as long as its apical width; clypeus with a central tubercle or production, beyond which it is beveled to edge....

Gular orifice at its anterior margin much wider than space between anterior extremities of gular carina and eye; first abdominal segment not nearly twice as long as its apical width

2. Clypeus with a distinct central beveled emargination and a slight raised point

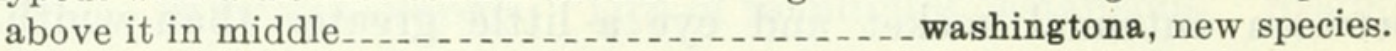

Clypeus with an elevated sharp transverse apical tip beyond which there is no beveled edge.....

3. First abdominal segment not much more than half as wide at apex as it is long._.

First abdominal segment nearly as wide at apex as it is long_-glabrella Cresson. 
BRACHYCISTIS (BRACHYCISTIS) NITIDA (Cresson)

This is a rather distinct species, distinguished from its allies by the narrow gular orifice, and elongated first abdominal segment. The space between eye and posterior ocelli is distinctly narrower than the transverse diameter of either ocellus, the head is yellow, forehead with sparse minute punctures; space between eye and antennal socket about as wide as socket; clypeus bevelled in the space between edge and central elevation, the submedian angles prominent but not toothed; gular carina erect to anterior extremities; mandibles stout, curved, sharp edged above on apical half but without a noticeable angle basally. Propodeum rather elongate, rounded above, and with a more or less evident central sulcus. Hind tibia with quite pronounced dorsal bristles, which are set on slightly elevated bases. Marginal cell as in inaequatis Fox.

Length, 11-14 mm.

There is a paratype from Colorado in the United States National Museum.

Paratype-Cat. No. 1667, U.S.N.M.

In addition to this I have before me specimens from Colorado, New Mexico, and Lincoln, Nebr. Bradley records it also from Arizona.

BRACHYCISTIS (BRACHYCISTIS) WASHINGTONA, new species

Male.-Brownish-orange, upper half of head, tips of mandibles, and stigma blackish.

Posterior ocelli about 1.5 as wide as space between either and eye, the distance between anterior and posterior ocelli a little over half as wide as that between posterior ocelli and eye; usually two or four elevated points above antennal insertions; clypeus with a rounded central emargination above the middle of the beveled edge of which there is a small raised point, the rim on which it is situated quite rounded; gular carina slightly flared to side anteriorly, widely separated from condyle. Propodeum stout, with setiferous punctures on posterior side and on upper part of sides. Basal segment of abdomen about two-thirds as wide at apex as long on sides. Marginal cell similar to that of inaequalis Fox. Hind tibia with or without one or two dorsal bristles.

Length, $12-13 \mathrm{~mm}$.

Holotype and three paratypes.-Ritzville, Wash., August, 1920 (R. C. Shannon).

Type and paratypes.-Cat. No. 27926, U.S.N.M.

BRACHYCISTIS (BRACHYCISTIS) NEVADENSIS Fox

A specimen which runs to this species in Bradley's key is very difficult to distinguish from those I consider are glabrella Cresson. In fact the only character upon which it is separable, the comparative 
length and width of the first abdominal segment is rather a variable and unreliable one in this group.

Originally described from Nevada. The specimen I assign here is from Luna, N. Mex., June, 1916 (J. G. Crick).

\section{BRACHYCISTIS (BRACHYCISTIS) GLABRELLA Cresson}

Originally described from Colorado. I have specimens evidently belonging to this species from Arizona, Texas, New Mexico, Colorado, and South Dakota.

One specimen from Texas is only $7 \mathrm{~mm}$. in length; the average length of the series is over $10 \mathrm{~mm}$.

\section{ATRATA group}

Characters.-This group has the gular carina elevated and deflected at or near the anterior extremities, the highest points visible below the mandibular condyle when the head is viewed directly from the side, or if the elevation is barely or not visible the vein emanating from the apical costal angle of the stigma turns downward at less than the length of the cross vein emanating from hind side of the stigma from apex of latter.

KEY TO SPECIES

1. Gular carina very low, not elevated at anterior extremities, not visible below condyle from side, distance from anterior extremity to condyle about half as great as anterior width of gular orifice; mandible distinctly angulate near base; propodeum rounded, microscopically shagreened dorsally, and with very faint sulcate line from anterior margin; the vein emanating from apical costal margin of stigma bent downward at base_... imitans, new species.

Gular carina more or less distinctly elevated and outwardly deflected at or near anterior extremities, frequently visible below condyle when head is seen from the side, and not so far distant from condyle.............2.

2. At least the head and thorax shining black

Thorax brownish orange or castaneous, head sometimes black above___ 5 .

3. Central tubercle on clypeus very prominent; anterior extremities of gular carina vertical, not flared outward, distant from mandibular condyle by three or four times the width of apical segment of maxillary palpus; vein emitted from apical costal angle of stigma paralleling costa for a short distance before bending downward; propodeum granulose or rugose at the edge of the rather vertical posterior portion, dorsum with a quite pronounced median longitudinal sulcus_................_._lacustris, new species.

Central tubercle on clypeus poorly developed; anterior extremities of gular carina flared outward, usually quite distinctly visible from side ... . . . . . 4 .

4. Dorsal surface of propodeum entirely, or for the greater part, obviously shagreened, and not highly polished; abdomen more brown or reddishbrown than black; frons in front of ocelli with scattered punctures, no large one in front of anterior ocellus................ semiatra, new species.

Dorsal surface of propodeum highly polished and smooth exeept for the faint median longitudinal sulcus; abdomen normally entirely black; frons in front of ocelli polished, almost impunctate except for a large, deep pit or puncture just in front of anterior ocellus atrata (Blake.) 
5. Posterior ocelli separated from eye by at least 1.5 as great a distance as the transverse diameter of either ocellus........... (see micrommata group.)

Posterior ocelli separated from eye by much less than 1.5 as great a distance as transverse diameter of either ocellus .

6. Anterior elevations of gular carina large, a line drawn across their highest points would pass distinctly behind the mandibular condyles; small brownish-orange species with black head._._._._._._. indiscreta Fox.

Anterior elevations of gular carina moderate in height, a line drawn transversely across their highest points would pass over the mandibular condyles, sometimes beyond their highest points 7.

7. Space between antennal socket and eye not over half as wide as socket (see inaequalis group. ${ }^{2}$ )

Space between antennal socket and eye well over half as wide as socket_._. 8 .

8. Propodeum short and broad, the horizontal anterior part broader than long, rather sharply marked off from the precipitous posterior portion and the sides; basal segment of abdomen seen from the side of its highest part about two-thirds as high as its length on lateral suture; an arcuate frontal carina over each antenna; head brownish orange_... triangularis Cresson.

Propodeum longer, sloping downward from about middle; basal segment of abdomen seen from the side not half as high as long; no arcuate frontal carinae over antennae; head black or fuscous, much darker than thorax dentata Bradley.

BRACHYCISTIS (BRACHYCISTIS) IMITANS, new species

Male.-Head black, mandibles and antennae brownish orange. Thorax dark castaneous, paler on sides of prothorax and of mesonotum, the tegulae brownish-yellow. Abdomen castaneous, blackish apically. Tip brownish yellow, stigma fuscous.

Posterior ocelli at distinctly less than their transverse diameter from eye; space between eye and antennal socket a little narrower than socket; clypeus hardly elevated in center, the edge but little bevelled; carina from inner tooth to base complete and sharp, with a distinct angle near base; gular carina not obviously deflexed outwardly at apex, distant from edge about two-thirds of width of gular orifice. Mesopleura distinctly punctate; propodeum not as elongate as in atrata, the hind margin more abruptly declivous, surface not polished above but closely shagreened, the hind margin and upper part of sides with many setiferous punctures. First abdominal segment over 1.5 as long as its apical width, marginal cell as in Figure 23. Hind tibia without pronounced dorsal bristles.

Length, $7 \mathrm{~mm}$.

Holotype.-Los Angeles County, Calif., September (D. W. Coquillett).

Type.-Cat. No. 27927, U.S.N.M.

\section{BRACHYCISTIS (BRACHYCISTIS) ATRATA (Blake)}

This species as I interpret it is usually shining black in color, with the lower half of face, tibiae, and tarsi, and usually the pro-

2 For description see under inaequalis group. 
pleurae brownish-orange, though the pale color may be more or less extensive in individual specimens. The characters listed in the key may be amplified as follows: The propodeum is glossy above, usually without shagreening, and sometimes with a shallow median sulcus; the mandibles have no evident angle near base; the first abdominal segment is fully twice as long as its apical width; and the vein emanating from apical costal angle is curved downward almost immediately after leaving the stigma. Hypopygium as in Figure 53.

Length, 8-10 mm.

Originally described from Nevada and recorded from California. I have before me specimens from California and Nevada. One of the California specimens bears the name nigritus Fox (determined by Fox), and another contiguus Fox (determined by Ashmead). Bradley has suggested that nuda Fox, which he says is the same as nigritus, is not specifically distinct from atrata, of which he considers contiguus a synonym. I consider the names all apply to atrata, if the specimens before me are correctly identified.

\section{BRACHYCISTIS (BRACHYCISTIS) LACUSTRIS, new species}

Male.-Similar to atrata in color, differing essentially as stated in the foregoing key to species. In addition to these characters the frons in front of ocelli is more distinctly punctate, the pit in front of median ocellus is larger and broader, not like a single puncture, the antennae are brownish orange, and the basal segment of abdomen is shorter and higher as seen from the side. In other respects the species resemble each other.

Length, $9 \mathrm{~mm}$.

Type.-Cat. No. 27928, U.S.N.M. Sutcliffe Station, Pyramid Lake, Nev., May 27, 1924, in alfalfa field (C. R. Hall).

\section{BRACHYCISTIS (BRACHYCISTIS) SEMIATRA, new species}

Male.-Readily distinguished from atrata by the reddish brown color of basal portion of dorsum of abdomen and by the characters given in the key to species. In other respects the species are very similar.

Length, 8-11 mm.

Type and 6 paratypes.-Ritzville, Wash., June to August, 1923 (M. C. Lane and R. C. Shannon); type collected August 28, 1923, by M. C. Lane; one paratype, Pasco, Wash., September 11, 1904, at light.

Type and paratype-Cat. No. 27929, U. S. N. M.

Two specimens from Pyramid Lake, Nev., may belong to this species but are rather smaller and more uniform brownish fuscous in color. 
BRACHYCISTIS (BRACHYCISTIS) TRIANGULARIS Cresson

I identify as this species specimens from Hot Springs and Higley, Ariz., and Lordsburg, N. Mex.

Originally described from Arizona.

\section{BRACHYCISTIS (BRACHYCISTIS) INDISCRETA Fox}

I have before me a specimen from Wilcox, Ariz., which agrees with specimens, evidently from the type material, in the United States National Museum.

Bradley includes this species in his key but omits it in the treatment of the species.

\section{Brachycistis (Brachycistina), new subgenus}

This subgenus is distinguished from the other two by the presence of only one preapical mandibular tooth which is sometimes poorly developed.

Genotype.-Brachycistis (Brachycistina) acuta, new species.

There are two species referable here which may be distinguished as indicated below.

KEY TO SPECIES

Preapical tooth of mandibles poorly developed, an angle, apical tooth long and sharp (fig. 26) ; posterior ocelli separated from eye and from anterior ocellus by about twice as great a distance as their transverse diameter _ _ acuta, new species. Preapical tooth of mandibles well developed, apical tooth short and stout (fig. 25); posterior ocelli separated from eye and from anterior ocellus by about as great a distance as their own diameter elegantula (Cockerell and Casad).

BRACHYCISTIS (BRACHYCISTINA) ACUTA, new species

Male.-Pale brownish-orange, head fuscous above, tips of mandibles blackish; stigma pale-brown. Head subquadrate above; ocelli rather small; clypeus as in Figure 27, descending farther than in any other species known to me, the apex transverse, not bevelled and without submedian teeth, the central part with a rounded elevation which slopes evenly off on sides and below; gular orifice not over one-third wider than space between it and eye at anterior extremity, the carina low, not bevelled at anterior extremity; vertex with very few punctures. Propodeum short and robust, without distinct sculpture. Basal abdominal segment about as long as its apical width; hypopygium as in Figures 54 and 55. Hind tibia with two or three short bristles showing amongst the hairs; hind coxae not carinate. Fore wing in type with but two submarginal cells, the cross vein from stigma interstitial with vein closing second submarginal, the latter cell a little over half as long as first.

Length, $6 \mathrm{~mm}$.

Holotype-Arlington, Ariz. June 17, 1919 (A. Wetmore).

Type.-Cat. No. 27930, U.S.N.M.

Genitalia and apical segments of abdomen in vial with alcohol. 


\section{BRACHYCISTIS (BRACHYCISTINA) ELEGANTULA (Cockerell and Casad)}

Differs from preceding species as noted in key and also in the following particulars. The clypeus has a more prominent central elevation, the apical central portion is not so much produced downward and in addition the margin is bevelled, with a short but noticeable tooth on each angle of the produced central part. The basal segment of abdomen is distinctly longer than its apical width, and the hypopygium is similar to that of atrata Blake. There are three submarginal cells in the fore wing of all four specimens before me, including one labeled "type," the cross vein from stigma being well before the vein closing third submarginal cell (fig. 5).

Length, 6-8 $\mathrm{mm}$.

Originally described from Mesilla Park, N. Mex. I have seen a specimen from Chiricuhua Mountains, Arizona.

Type.-Cat. No. 2593, U.S.N.M.

\section{EXPLANATION OF PLATES}

Plate 1

Details of Brachycistiinae, Psammocharidae, and Cyphotinae

Fig. 1. Brachycistis carinata, prothorax of male from side.

1a. Ceropales texanus, same.

2. Brachycistis atraia, seventh and eighth abdominal sternites of male from below.

3. Brachycistis atrata, apex of abdomen of male from side, expanded to show hypopygium, etc.

4. Brachycistis amplus, fore wing of male.

5. Brachycistina elegantulus, same.

6. Brachycistis gaudii, same.

7. Brachycistis carinata, hind wing of male.

8. Brachycistis washingtona, apex of radius of hind wing, male.

9. Brachycistis carinata, same.

10. Cyphotes, species, same.

11. Mrymosa unicolor, same.

12. Myrmosa unicolor, cerci of male.

13. Cyphotes melaniceps, same.

14. Typhoctes mirabilis, side view of thorax of female. $P=$ prothorax, $M e=\operatorname{mesothorax}, M t=$ metathorax and propodeum, $A=$ abdomen, 1, 2, 3, fore, mid, and hind coxae.

15. Cyphotes melaniceps, base of abdomen of male.

16. Cyphotes species, same, female. 


\section{Plate 2}

Structural characters of Brachycistis males

FIG. 17. Brachycistis gaudii, stigma and adjoining cells of fore wing

18. Brachycistis stygia, same.

19. Brachycistis texana, same.

20. Brachycistis inaequalis, same.

21. Brachycistis noctivaga, same.

22. Brachycistis curvata, same.

23. Brachycistis imitans, same.

24. Brachycistis intermedia, same.

25. Brachycistina elegantula, mandible.

26. Brachycistina acuta, same.

27. Brachycistina acuta, clypeus from front.

28. Brachycistis normalis, one side of carina of gular orifice.

29. Brachycistis aequalis, same.

30. Brachycistis noctivaga, same.

31. Brachycistis indiscreta, same.

32. Brachycistis texana, same.

33. Brachycistis melanocephala, apex of clypeus from front.

34. Brachycistis texana, head from above.

35. Brachycistis ampla, same.

36. Brachycistis eremi, apex of hypopygial volsella and sagitta.

37. Brachycistis brevis, same.

38. Brachycistis brevis, uncus from side.

39. Brachycistis brevis, uncus from above.

40 Brachycistis ampla, hypopygium from side.

41. Brachycistis thermarum, same.

42. Brachycistis stygia, same.

\section{Plate 3}

Hypopygia of Brachycistis males

Fig. 43. Brachycistis normalis, left side dorsal, right ventral.

44. Brachycistis crassa, side view.

45. Brachycistis crassa, left side ventral right dorsal with dorsal and lateral views of apex of.

46. Brachycistis stygia, left side dorsal, right ventral $a . b$. and $c$ show characters of castanea.

47. Brachycistis thermarum same.

48. Brachycistis carinata, same.

49. Brachycistis texana, same.

50. Brachycistis eremi, same.

51. Brachycistis alcanor, same. 
Plate 4

Hypopygial characters of Brachycistis, Cyphotes, and Myrmosa males

Frg. 52. Brachycistis ampla, hypopygium, left side dorsal, left ventral.

53. Brachycistis atrata, same.

54. Brachycistina acula, hypopygium, side view.

55. Brachycistina acuta, same, dorsal view, one half.

56. Brachycistellus inermis, same.

57. Brachycistellus inermis, same, side view.

58. Cyphotes melaniceps, same.

59. Cyphotes melaniceps, same, left side ventral view, right side dorsal.

60. Cyphotes melaniceps, seventh and eighth ventral segments of abdomen from below.

61. Myrmosa unicolor, hypopygium, left side ventral view, right side dorsal.

62. Myrmosa unicolor, 7 th and 8th ventral segments of abdomen from below. 


\section{$2 \mathrm{BHL}$ Biodiversity Heritage Library}

Malloch, John Russell. 1926. "Systematic notes on and descriptions of North American wasps of the subfamily Brachycistiinae." Proceedings of the United States National Museum 68(2604), 1-28.

https://doi.org/10.5479/si.00963801.68-2604.1.

View This Item Online: $\underline{\text { https://www.biodiversitylibrary.org/item/32569 }}$

DOI: https://doi.org/10.5479/si.00963801.68-2604.1

Permalink: https://www.biodiversitylibrary.org/partpdf/5749

\section{Holding Institution}

Smithsonian Libraries

\section{Sponsored by}

Smithsonian

\section{Copyright \& Reuse}

Copyright Status: NOT_IN_COPYRIGHT

Rights: https://www.biodiversitylibrary.org/permissions/

This document was created from content at the Biodiversity Heritage Library, the world's largest open access digital library for biodiversity literature and archives. Visit BHL at https://www.biodiversitylibrary.org. 